\title{
Change of Acute Toxicity of Dyestuff Wastewaters
}

\author{
V. Zülal Sönmez ${ }^{1,2 *}$, Nüket Sivri ${ }^{1}$ \\ ${ }^{1}$ Department of Environmental Engineering, Istanbul University-Cerrahpasa, Istanbul, Turkey \\ ${ }^{2}$ Department of Environmental Engineering, Duzce University, Duzce, Turkey
}

Received: 16 August 2018

Accepted: 27 December 2018

\begin{abstract}
Dyes from different sources often behave with mostly toxic properties when they enter the aquatic ecosystem. The main sources of these toxic substances causing problems in the aquatic ecosystem are wastewaters of the textile and dye industries. The aim of this study was to examine the change of acute toxicity values of wastewaters containing dyestuff depending on time and color parameters. In this study, an acute toxicity test was conducted for 30 seconds, which is shorter than the time specified in the original Microtox test protocol. Thus, the results of the original Microtox Basic Test (BT), Microtox Color Correction Procedure recommended by the manufacturer (BT-CC), and the Microtox Basic Test-30 seconds (sBT) were compared, taking into account the effect of time and color parameters. There is a statistically significant difference between two groups: $\mathrm{BBT}$ and $\mathrm{BT}$, and $\mathrm{SBT}$ and BT-CC $(\mathrm{F}=4.919 ; \mathrm{p}<0.01)$. The results of $\mathrm{sBT}$ have been obtained more rapid and more sensitively than other acute toxicity tests. The sBT, which is time-saving and gives correct result might provide some guidance as a pre-screening test and might be used in routine monitoring.
\end{abstract}

Keywords: dyestuff wastewater, acute toxicity test, bioluminescent bacteria, Microtox, color correction procedure

\section{Introduction}

Industrial wastewaters containing dyestuff (textile, leather, food, paper, chemical and petrochemical industries) have a variety of characteristic features [1]. The wastewater composition consists of organic and inorganic compounds, chemicals and dyes [2]. Due to its complex structure, namely aromatic rings that afford highly optical and physicochemical stability, dyes are known to be recalcitrant toxic pollutants with carcinogenic and mutagenic potential [3-4]. Generally, dyestuffs with low biodegradability pass through the

*e-mail: zulal.kiremitci@istanbul.edu.tr wastewater treatment plant and are released into the environment [5]. In addition to traditional treatment methods, advanced treatment methods (membraneseparating technology, adsorption, ozone oxidation, electrochemical oxidation, photo-Fenton process, and $\mathrm{UV} / \mathrm{H}_{2} \mathrm{O}_{2}$ ) have been needed for dye removal [5-7], although a by-product that may be produced during treatment methods can be more toxic than dyes [8].

Many complex and aromatic dyes due to their incomplete degradation and accumulation display toxic effects in aquatic ecosystems and public health [3]. It is important to evaluate the dyes considering the ecotoxic effects on aquatic organisms [9], although determination of toxic effects takes a longer time than physicochemical parameters. However, the acute toxicity test should be as rapid as possible and result 
within seconds. In recent years we have seen that acute toxicity tests with bioluminescent bacteria, a rapidscreening acute toxicity test, can give results within minutes compared to the other acute toxicities [10-13].

In the acute toxicity test carried out with bioluminescent bacteria on colored wastewaters as well as some natural samples, the main thing is that color and turbidity scatter the light and are being seen as toxicity [14]. When the bacteria are exposed to toxic substances, bacterial luciferase is inhibited and light is rapidly reduced [15]. Although humic acid compounds are nontoxic, they raise secondary problems when determining toxicity [16]. If the color originates from turbidity, suspended solids or emulsified matters, it effects the optical emission from the bioluminescent bacteria since it absorbs or reflects the light and causes interaction in the test results. In accordance with ISO 11348-3 [17], it is stated that the sample should be especially filtrated if it is turbid [18]. In addition, if the toxicity is directly associated with the particles, this conducted pretreatment may cause a decrease in toxicity [19].

The Microtox (M500) analyzer is a laboratorybased photometer that measures acute toxicity, the interaction caused by the color and turbidity has been attempted to be prevented through the color correction procedure prepared by the producing company [15]. In the following years, in order to prevent the interaction caused by the color and turbidity, Flash Assay developed by Lappalainen et al. [18] has been accepted as ISO 21338:2010 standard [20]. Unfortunately, the Microtox (M500) analyzer is not a suitable device to carry out flash assay because the device is only intended to measure the luminescence of the bacterial population manually set at the specified times $(5,15$ and 30$)$. It cannot measure a continuous luminescence at a given time interval (e.g., 5-10 minutes) and at the same time does not have the mixing feature. It only conducts a mathematical correction equivalent to the absorbance values of the samples at a wavelength of $490 \mathrm{~nm}$ for color correction. So, researchers studying with different analyzers have also preferred the different color correction procedure for solving this problem [21-24].

The aim of this study was to examine the change of acute toxicity values of wastewaters containing dyestuff depending on time and color parameters. To this end, toxic/non-toxic synthetic samples were prepared, in particular in accordance with the scale of the color parameter of the textile industry wastewaters. Acute toxicity tests with bioluminescent bacteria were performed by taking into account the effect of the color parameter on toxicity. In this study, an acute toxicity test was conducted with 30 seconds, which is shorter than the time specified in the original Microtox ${ }^{\circledR}$ test protocol. It was named Microtox Basic Test-30 seconds (sBT). Thus, the results of the original Microtox Basic Test (BT), Microtox Color Correction Procedure recommended by the manufacturer (BT-CC), and the Microtox Basic Test30 seconds (sBT) were compared, taking into account the effect of time and color parameters.

\section{Material and Methods}

The studied dyes were selected according to the color of wastewater containing dyestuff in the project report prepared by Turkish Ministry of Environment and Urbanization and TUBITAK [25]. It used dyes with blue and purple wavelengths and which were included in the scale of the color parameter of the textile industry wastewaters as to the report. Samples were prepared with different dyes and sets were formed. These sets were tested via a Microtox Model 500 analyser and the acute toxicity results were given as $\mathrm{EC}_{50}(\mathrm{mg} / \mathrm{L})$. Sets and methods used in the conducted study were explained in the following headings.

\section{Preparation of Dye Sets}

In order to define the effect of color parameters, sets prepared with different chemicals consisting of food dye, methylene blue, crystal violet and formaldehyde were used. Methylene blue, crystal violet and formaldehyde were prepared by diluting with distilled water at concentrations which their toxicity could be analyzed. The concentration of food dye was prepared according to the instructions for use. According to this, the Brilliant Blue Food Dye (KRK- Brilliant Blue - E133 CAS No: 6104-59-2) is non-toxic. Methylene blue (Merck-Methylene Blue CAS No: 122965-439) has the same color but is toxic. In order to reveal the effect of color apart from blue, crystal violet (Merck - Crystal violet CAS No: 548-62-9) was included in this study. Another chemical used in the study is formaldehyde (Merck-Formaldehyde 37\% Pure CAS No: 1.040.021.000). In addition, the synthetic toxicity was formed by adding formaldehyde, which is colorless and toxic, to the non-toxic food dye. Besides, the synthetic extreme toxicity was formed by adding formaldehyde, which is colorless and toxic, to the toxic methylene blue and crystal violet. Thus, it was aimed to the toxic effects of the possible interactions depending on the color parameter. Acute toxicity values of four different chemicals, which were defined as Set X, were measured via Microtox. In order to determine the correlation between color and luminescence; the analyses were studied with various concentrations of methylene blue in Set Y. All samples were studied as 2 parallels with control sample; calculations were made over the average of toxicity values. All of the studied dye sets were summarized in Table 1.

\section{Change of Acute Toxicity Tests with Bioluminescent Bacteria}

The Microtox acute toxicity test is based on luminescence inhibition of the marine gram negative bacteria. Lyophilized Vibrio fischeri (NRRLB-11177) was used as test organism; the test was carried out in standard producer protocol [15] and ISO 11348-3:2007 
Table 1. Dye sets.

\begin{tabular}{|c|c|}
\hline SET X & SET Y \\
\hline Food dye (non-toxic) & \\
Methlyene blue & Concentrations of \\
Cristal violet & Methlyene blue \\
Formaldehyde & $(5,10,15,20,25$, \\
Food dye (non-toxic) + Formaldehyde & $30,35,40,45,50$ \\
Methlyene blue + Formaldehyde & mg/L) \\
Cristal violet + Formaldehyde & \\
\hline
\end{tabular}

[17]. Bacterial suspension was added to the sample osmotically arranged with $2 \% \mathrm{NaCl}$ and to the sample dilutions. After the bacteria were exposed to the sample, photometry was carried out periodically. Acute toxicity tests were carried out in the Microtox Model 500 analyzer. Moreover, formaldehyde (volume rate of $0.08 \%$ ), known to be colorless and toxic, was preferred as a control chemical in toxicity tests [26].

\section{Basic Test (45\%) (BT)}

The basic test $(45 \%)$ recommended by the manufacturer for samples that have unknown toxicity and wastewater was applied. 5, 15 and 30 minutes were selected as exposure times and $\mathrm{EC}_{50}$ values were found.

\section{Basic Test (45\%) - Color Correction Procedure (BT-CC)}

After the results of the Basic Test (45\%) were obtained, the Microtox Color Correction Procedure (BTCC) was applied to the test results. The procedure, which is based on a mathematical correction, was applied to determine the effect of color on toxicity. According to this procedure, spectrophotometer readings were made at a wavelength of $490 \mathrm{~nm}$. It recorded the percentage absorbance (ABSx) for each of the concentrations. $\mathrm{EC}_{50}$ values were calculated by Microtox Omni software for all exposure times (5, 15 and 30 minutes) [15].

\section{Basic Test (45\%) - 30 seconds (sBT)}

30 seconds as exposure time, which is shorter than the exposure time specified in the original Microtox test protocol, was studied. The mixture of the sample and the bacteria suspension were mixed in vortex and the bacterial luminescence was measured at the end of 30 seconds. $\mathrm{sBT}$ is a toxicity test that has been investigated at 30 seconds.

\section{Statistical Analysis}

Repeated measure ANOVA Test- SPSS 17.0 was applied in order to determine the statistical significance of the differences in the results of the acute toxicity tests.

\section{Results and Discussion}

Basic Test (45\%)

The results of this test conducted to determine the acute toxicity of each chemical are given in Table 2. $\mathrm{EC}_{50}$ values of food dye, known to be non-toxic, exceeded $100 \mathrm{mg} / \mathrm{L}$ (or \%). However, the toxicity of food dye was found to increase at the 30th minute. This case was explained as pseudo-toxicity. The acute toxicity of methylene blue at all exposure times was determined as 6.54, 6.42 and $7.00 \mathrm{mg} / \mathrm{L}$, respectively (Table 2). In addition, the acute toxicity value of methylene blue, another dye in this study, was compared with the study of Fungaro et al. [27]. Accordingly, it was found that the acute toxicity value of methylene blue varied between $15.55 \mathrm{mg} / \mathrm{L}$ and $18.64 \mathrm{mg} / \mathrm{L}$. Hence, methylene blue has been determined to be toxic in the results of both studies and results have supported each other. The same case was seen for Crystal violet (14.15; 9.97 and 8.86 $\mathrm{mg} / \mathrm{L})$. When the literature was examined, the results of the acute toxicity of crystal violet were found to be $0.3 \mathrm{mg} / \mathrm{L}$ and $4.7 \mathrm{mg} / \mathrm{L}$ [28-29]. When the differences of concentration of crystal violet used are taken into account, it is seen that the results of this study overlap with the other study results. So, the toxicity results of this and other studies have been classified as extremely toxic. Toxicity results of formaldehyde, known to be extremely toxic and used as control, were found to be 2.30, 2.14 and $2.17 \mathrm{mg} / \mathrm{L}$, respectively. $\mathrm{EC}_{50}$ values of the synthetically prepared toxic mixture (Methylene blue + Formaldehyde) were found to be 2.23 and $1.89 \mathrm{mg} / \mathrm{L}$, respectively at the $5^{\text {th }}$ and $15^{\text {th }}$ minutes. At 30 minutes, it was determined that concentration change was needed. Because the analyzer was unable to measured enough luminescence for calculating $\mathrm{EC}_{50}$ value at 30 minutes.

The results of Set $\mathrm{Y}$ are given in Fig. 1. Accordingly, as the concentration of methylene blue (the value of

Table $2 . \mathrm{EC}_{50}(\mathrm{mg} / \mathrm{L})$ values of Set $\mathrm{X}$ at 5, 15 and 30 minutes.

\begin{tabular}{|c|c|c|c|}
\hline \multirow{2}{*}{ SET X } & \multicolumn{3}{|c|}{$\mathrm{EC}_{50}(\mathrm{mg} / \mathrm{L})$} \\
\cline { 2 - 4 } & $5 \mathrm{~min}$. & $15 \mathrm{~min}$. & $30 \mathrm{~min}$. \\
\hline Food dye & $>100$ & $>100$ & 92.38 \\
\hline Cyrstal violet & 14.15 & 9.97 & 8.86 \\
\hline Methylene blue & 6.54 & 6.42 & 7.00 \\
\hline Formaldehyde & 2.30 & 2.14 & 2.17 \\
\hline FDF & 1.64 & 1.70 & 1.67 \\
\hline CVF & 1.61 & Re-testing & Re-testing \\
\hline MBF & 2.23 & 1.89 & Re-testing \\
\hline
\end{tabular}

$(\mathrm{FD}=$ Food dye. $\mathrm{CV}=$ Crystal violet. $\mathrm{MB}=$ Methylene blue. $\mathrm{F}=$ Formaldehyde.

$\mathrm{FDF}=$ Food dye + Formaldehyde $. \mathrm{CVF}=$ Crystal violet +

Formaldehyde. $\mathrm{MBF}=$ Methylene blue + Formaldehyde) 


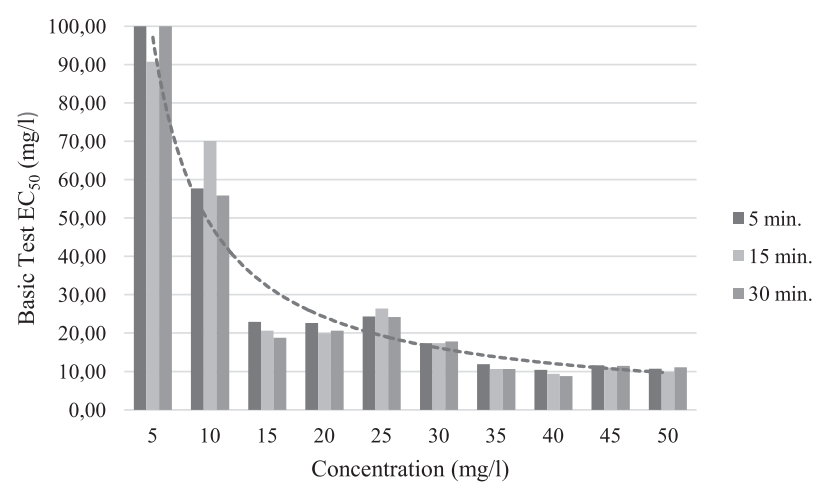

Fig. 1. $\mathrm{EC}_{50}(\mathrm{mg} / \mathrm{L})$ values of Set $\mathrm{Y}$ at 5,15 and 30 minutes.

the color parameter) increased, the acute toxicity also increased. The toxicity values obtained at concentrations of $25 \mathrm{mg} / \mathrm{L}$ and $45 \mathrm{mg} / \mathrm{L}$ attracted notice. These methylene blue concentrations were found to be less toxic than their previous methylene blue concentrations.

\section{Comparison of sBT and BT}

The luminescence of bacteria was measured before and after exposure to the samples in Set X. The luminescence changes of two tests were given in Fig. 2 in order to understand the difference between the original test (BT) and the rapid test (sBT). We found that the lowest luminescence change was observed in control samples (dye is not added, containing only $\mathrm{NaCl}$ ) of sBT. When the life stage of the bacteria participates in the account, the longer the exposure time, the more likely the reduction in the luminescence in the control. As the exposure time increased, the difference between the luminescence increased generally. The lowest luminescence change of different dilutions $(5.63 \%, 11.25 \%, 22.50 \%, 45.00 \%)$ of the samples was determined in the sBT.

Methylene blue concentrations were analyzed for all exposure times. The results were presented in Table 3 among BT results on behalf of the comparison of luminescence at the shortest $(30 \mathrm{sec})$ and the longest (30 min) exposure times. It was found that the lowest luminescence change was observed at 30 seconds (sBT). Since the exposure time was as short as 30 seconds, it could be assumed that no color interaction occurred. When the control samples in Table 3 were examined, the luminescence change at the 30th minute was the highest value (25.945). There were also control samples in which the luminescence change did not happen at $30 \mathrm{sec}$. In other words, there was no luminescence decrease due to the short exposure time. Also, at different dilutions of the methylene blue concentrations, sBT was seen as the test with the lowest luminescence change. This change could result from both exposure time and color. In this sense, examining the results of
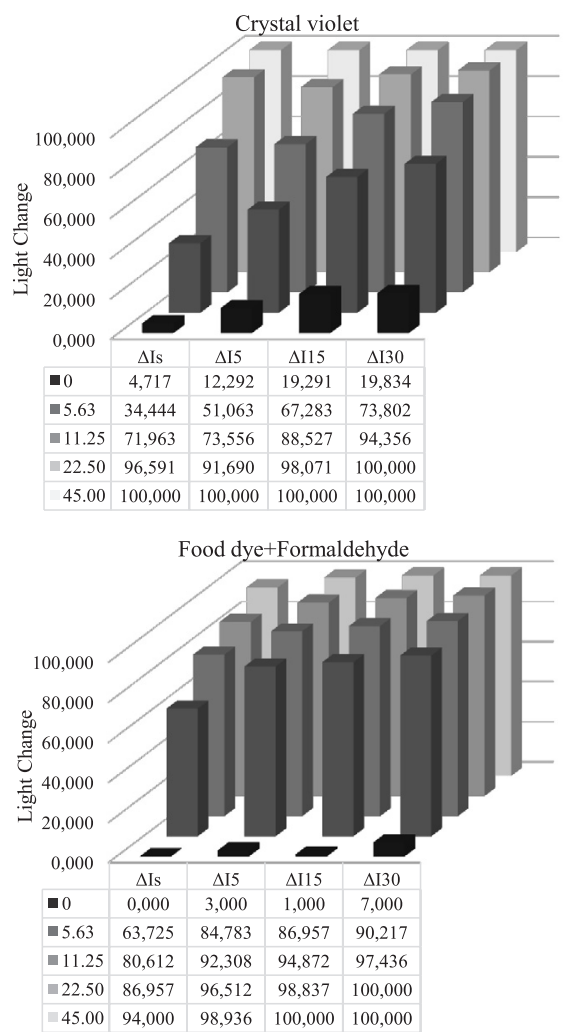
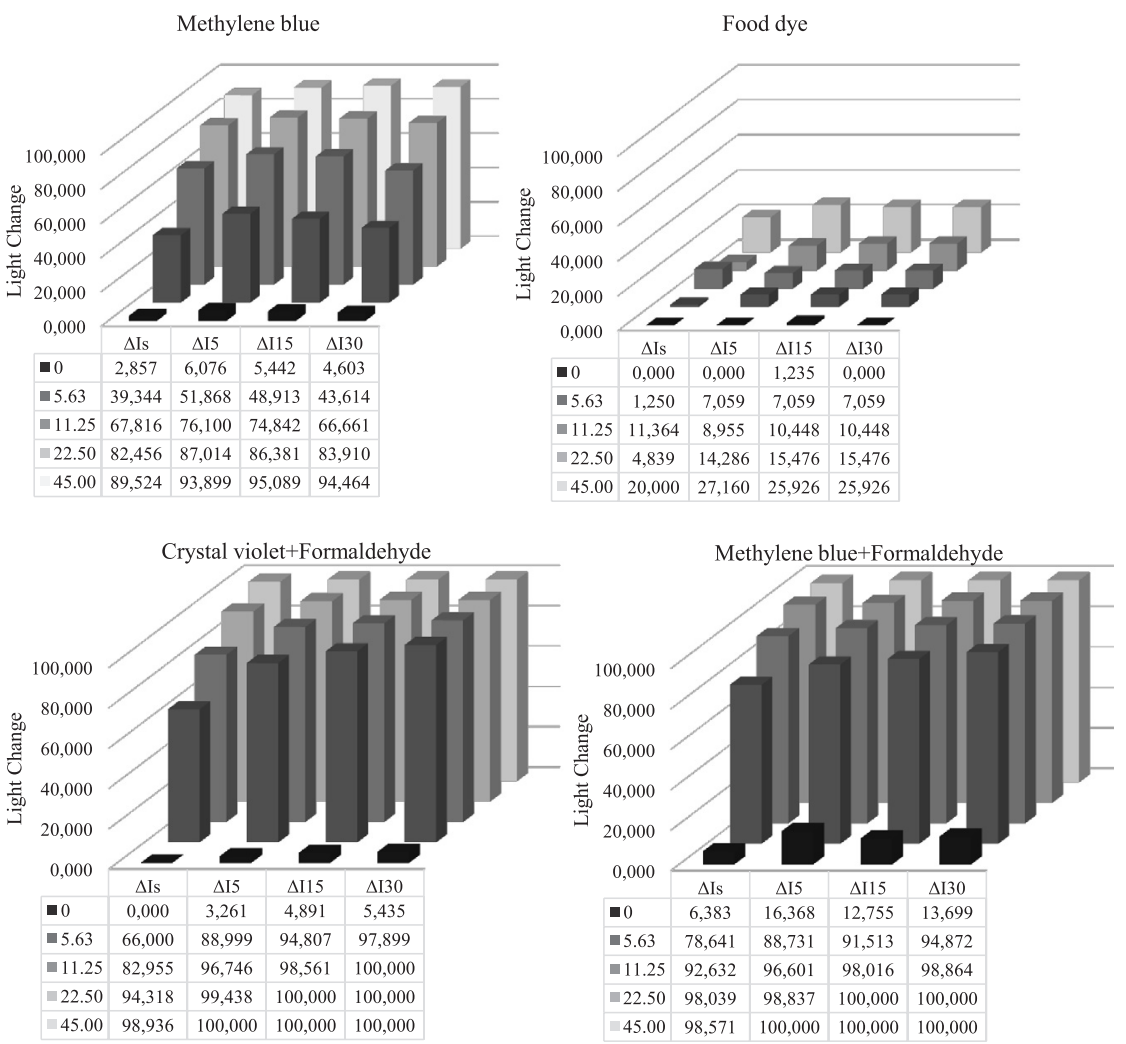

Fig. 2. Luminescence changes in Set $X$.

$\left(\Delta \mathrm{I}_{\mathrm{s}}=\right.$ Luminescence change at $30 \mathrm{sec}, \Delta \mathrm{I}_{5=}$ Luminescence change at $5 \mathrm{~min}, \Delta \mathrm{I}_{15=}$ Luminescence change at 15 min, $\Delta \mathrm{I}_{30}=$ Luminescence change at $30 \mathrm{~min}$ ) 
Table 3. Luminescence change at sample concentration for Set Y.

\begin{tabular}{|c|c|c|c|c|c|c|c|c|c|c|c|}
\hline \multirow{2}{*}{\multicolumn{2}{|c|}{\begin{tabular}{|c|}
$\begin{array}{c}\text { Luminescence } \\
\text { Change at Exposure } \\
\text { Time }\end{array}$ \\
Dilution (\%)
\end{tabular}}} & \multicolumn{5}{|c|}{$\Delta \mathrm{I}_{\mathrm{s}}$} & \multicolumn{5}{|c|}{$\Delta \mathrm{I}_{30}$} \\
\hline & & 0.00 & 5.63 & 11.25 & 22.50 & 45.00 & 0.00 & 5.63 & 11.25 & 22.50 & 45.00 \\
\hline \multirow{10}{*}{$\begin{array}{c}\text { Concen- } \\
\text { tration } \\
(\mathrm{mg} / \mathrm{L})\end{array}$} & 5 & 0.000 & 0.000 & 5.618 & 10.390 & 20.652 & 1.064 & 3.883 & 5.495 & 21.978 & 28.571 \\
\hline & 10 & 0.000 & 3.488 & 17.073 & 25.000 & 44.262 & 25.945 & 39.781 & 42.624 & 50.999 & 58.973 \\
\hline & 15 & 0.000 & 9.392 & 27.778 & 40.426 & 67.081 & 8.370 & 25.686 & 29.929 & 45.188 & 76.128 \\
\hline & 20 & 1.124 & 9.859 & 6.557 & 30.392 & 52.174 & 20.806 & 31.724 & 37.107 & 63.433 & 81.197 \\
\hline & 25 & 0.000 & 15.116 & 22.222 & 32.877 & 58.333 & 14.239 & 30.582 & 42.436 & 52.672 & 75.514 \\
\hline & 30 & 2.174 & 17.021 & 28.736 & 42.857 & 66.372 & 14.239 & 30.582 & 42.436 & 52.672 & 75.514 \\
\hline & 35 & 0.000 & 10.000 & 15.116 & 40.860 & 60.256 & 5.560 & 27.397 & 36.709 & 86.250 & 97.647 \\
\hline & 40 & 3.740 & 18.868 & 26.374 & 54.737 & 73.118 & 7.690 & 35.211 & 60.274 & 84.615 & 100.000 \\
\hline & 45 & 0.000 & 26.596 & 39.175 & 55.932 & 77.778 & 2.150 & 16.304 & 46.988 & 77.273 & 97.849 \\
\hline & 50 & 5.825 & 15.385 & 35.644 & 54.630 & 70.588 & 11.828 & 18.889 & 46.237 & 73.864 & 95.402 \\
\hline
\end{tabular}

$\left(\Delta \mathrm{I}_{\mathrm{s}}=\right.$ Luminescence change at $30 \mathrm{sec} . \Delta \mathrm{I}_{30}=$ Luminescence change at $\left.30 \mathrm{~min}\right)$

the control samples was meaningful for the change of luminescence. However, it was not possible to see the effect of the color parameter. While acute toxicity has been calculated by Microtox Omni software, the change in the control sample has been considered. Thus, the error contributed by luminescence decrease caused by the length of exposure time has been minimized. For this reason, the difference of $\mathrm{EC}_{50}$ values of methylene blue concentrations has been thought to result from the change in color parameters.

According to the analysis on the correlation between $\mathrm{BT}$ and $\mathrm{sBT}$, it was found that there was a linear and strong relationship $\left(\mathrm{R}^{2}=0.954 ; \mathrm{R}^{2}=0.919 ; \mathrm{R}^{2}=0.945\right.$; $\mathrm{p}<0.01$ ) (Fig. 3). Firstly, it could be said that sBT and BT were in concordance with each other. However, the difference between $\mathrm{EC}_{50}$ was also remarkable. This case associated that $\mathrm{SBT}$, which was compatible with $\mathrm{BT}$, had higher sensitivity.

\section{Comparison of Acute Toxicity Tests with Each Other}

The BT-CC has been based on the abs value of the sample read with $490 \mathrm{~nm}$ wavelength and the correction on the toxicity result. The luminescence was not change based on the exposure time as BBT. BT-CC was applied to the samples in Sets $\mathrm{X}$ and $\mathrm{Y}$. Thereupon, it was compared before and after color correction regardless of set distinction. The correlation between BT and BT-CC was found to be a linear function as presented in Fig. 4. The highest correlation was detected at $15 \min \left(\mathrm{R}^{2}=0.988, \mathrm{p}<0.01\right)$; the lowest correlation was found at $30 \mathrm{~min}\left(\mathrm{R}^{2}=0.907 ; \mathrm{p}<0.01\right)$. Literature about bioluminescence bacteria predicting toxicity of dyestuffs about color interaction is scant. In the study of Fungaro et al. [27], Microtox color correction was performed in order to prevent the hard blue color observed in the samples. There were other studies [30-31] using Microtox Color Correction, but the toxicity values after and before color correction were not compared. In another study conducted by Tsiridis et al. [32] for the toxicity detection of humic acid, a reading was made at $490 \mathrm{~nm}$ wavelength and color correction was performed. At the end of the color correction, it was found that the effect of the color in a given unit on the acute toxicity was at a negligible level and did not change the toxicity result. In another study conducted by Ashworth et al. [33], acute toxicity values of different products before and after color correction were found; no effective change was found on the acute toxicity results of products such as tea, coffee, soybean, etc. It was found that the color correction performed in accordance with the protocol at $490 \mathrm{~nm}$ wavelength had no effect. The results obtained

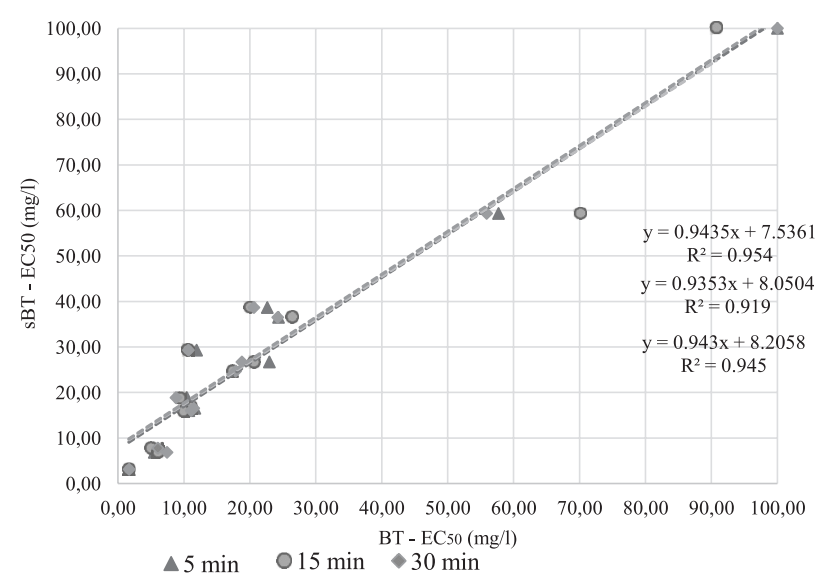

Fig. 3. Correlation between $\mathrm{sBT}$ and BT. 


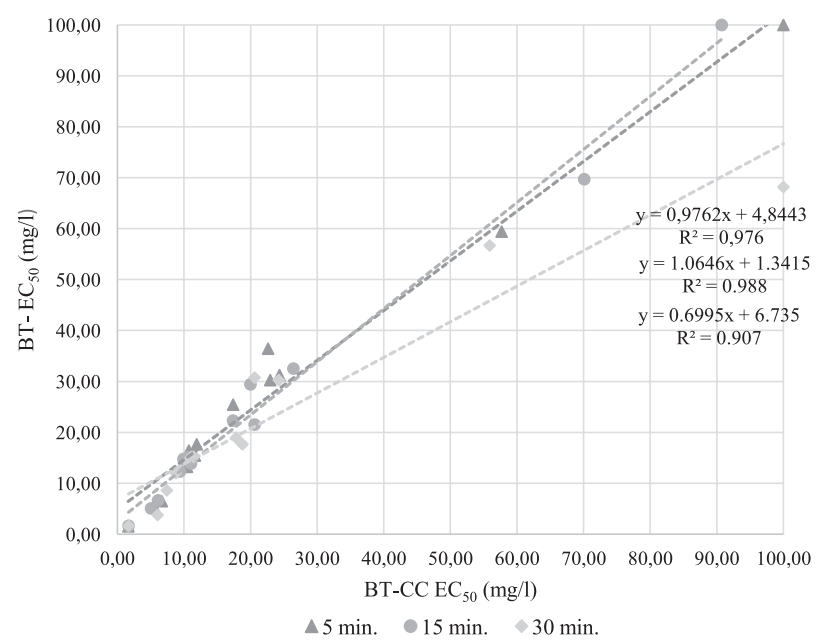

Fig. 4. Correlation of BT and BT-CC toxicity values at different exposure times $(5,15$ and $30 \mathrm{~min}$.) for all samples.

with BT-CC and BT in the present study has been in parallel with the literature findings.

The analysis on the correlation between sBT and BT-CC has indicated a linear function and high correlation with $\mathrm{R}^{2}=0.980$ at $5 \mathrm{~min}$. $(\mathrm{p}<0.01)$ (Fig. 5). This relationship is stronger than between BT and BT$\mathrm{CC}$ at $5 \min \left(\mathrm{R}^{2}=0.976, \mathrm{p}<0.01\right)$. An alternative assay incorporating color and turbidity correction, referred to as kinetic/flash assay, was first proposed by Lappalainen et al. [18] using a commercial test kit. To this end, sBT was developed on the basis of the rapid time $(30 \mathrm{sec}$.) inspired by Lappalainen et al. [18]. Furthermore, the Color Correction Procedure (BT-CC) recommended by the producer company has been applied in this study. When the results are compared, it can be seen that the tests are compatible with each other. Furthermore, statistically SBT has a significant difference, especially according to the results obtained from BT $(5,15$ and $30 \mathrm{~min})$ and BT-CC (30 min). This significant difference also investigates when the luminescence change is examined.

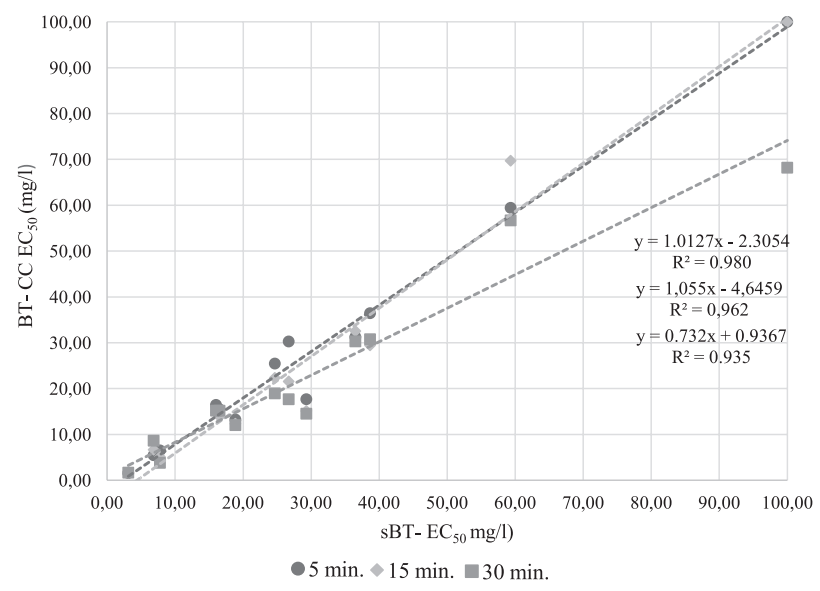

Fig. 5. Correlation of BT-CC and sBT toxicity values for all samples.
The kinetic bioluminescence inhibition assay-flashassay (but not the Microtox test format) was conducted [34-36]. In a study conducted by Kurvet et al. [34], it was studied 30 seconds, 15 and 30 minutes as exposure time, it was found that the results varied according to the chemical characterization of the studied sample. In this case, the toxicity value of $\mathrm{Cu}^{2+}$ was the highest in 30 minutes, while it was seen that the toxicity value was decreased as the exposure time increased in other samples (3,5 - DCA and aniline). Toxicity was measured with ToxAlert 100 and Flash in the study of Kovats et al. [37]. It was found that the luminescent bacterium test (Microtox/ToxAlert) turbidity and color of the sample might cause a significant decrease of light output due to physical effects, creating the potential for false-positives. It was determined that fundamental differences between the protocols/results of Microtox/ToxAlert and flash assay. The results of this study have overlaped with conclusions from other studies.

There is no study of Microtox acute toxicity test-30 seconds in literature, but there are many studies about the kinetic method, and suitable analyzers have been used. For this reason, no comparison could be made on numerical values. The lack of a kinetic method of measurement of Microtox was a limiting aspect of this study. However, the shortest possible time $(30 \mathrm{sec}$.) has been studied for the present Microtox toxicity test. In order to avoid color interference and to determine the faster feasibility of the test, studies with shorter exposure times should be carried out.

\section{Statistical Analysis}

Repeated Measure ANOVA Test, SPSS 17.0 was used. A significant difference was found between the administered acute toxicity tests $(\mathrm{F}=4.919$; $\mathrm{p}<0.01)$. The most important data has been that there was significant difference among SBT and BT (all exposure times). Moreover, it was found that there was significant difference among $\mathrm{SBT}$ and $\mathrm{BT}-\mathrm{CC}(30 \mathrm{~min})$. Although the results obtained have been numerically close to each other, the difference has been statistically significant.

\section{Conclusions}

The dyes that color our globe have become marketing strategies in the world thanks to their vivid colors as a result of chemical structures of dyes becoming brighter and more resistant to sunlight. However, these properties make them more recalcitrant and more toxic than other pollutants. The presence of these toxic substances in micro-levels in the receiving environment can be enough to change the balance in aquatic ecosystems. For this reason, just as with other parameters, it is important to estimate the toxicity correctly. The use and development of bioluminescence bacteria has increased due to the rapid acute toxicity test. However, more reliable color 
and turbidity corrections are needed. Provided that it is preferred sBT for determining acute toxicity of dyestuff wastewater, the results can be obtained more rapid and more sensitively. sBT might be used as a pre-screening test in routine monitoring for determining dyestuff wastewater toxicity.

\section{Acknowledgements}

This work was supported by the Research Fund of Istanbul University (BAP YL- Project No. 3153).

\section{Conflict of Interest}

The authors declare no conflict of interest.

\section{References}

1. NAGHIZADEH A., KAMRANIFAR M., YARI A.R., MOHAMMADI M.J. Equilibrium and kinetics study of reactive dyes removal from aqueous solutions by bentonite nanoparticles. Desalination and Water Treatment. 97, 329, 2017.

2. CARMEN Z., DANIELA S. Textile organic dyescharacteristics, polluting effects and separation/elimination procedures from industrial effluents - a critical overview. In Organic pollutants ten years after the Stockholm convention-environmental and analytical update. InTech. 2012.

3. EKAMBARAM S.P., PERUMAL S.S., RAJENDRAN D., SAMIVEL D., KHAN M. N. New Approach of Dye Removal in Textile Effluent: A Cost-Effective Management for Cleanup of Toxic Dyes in Textile Effluent by Water Hyacinth. In Toxicity and Biodegradation Testing. Humana Press, New York, NY., 241, 2018.

4. BIGLARI H., RODRÍGUEZÍCOUTO S., KHANIABADI Y.O., NOURMORADI H., KHOSHGOFTAR M., AMRANE A., VOSOUGHI M., ESMAEILI S., HEYDARI R., MOHAMMADI M.J., RASHIDI R. Cationic surfactant-modified clay as an adsorbent for the removal of synthetic dyes from aqueous solutions. International journal of chemical reactor engineering. 16 (5), 20170064 , 2018.

5. LI-HONG Y., YU-JUN W., LAN L., YUE-HUA Z. Univariate Degradation of Indigo Carmine in Aqueous Solution by Inactivated Biomass in Heterobasidion Insulare: Preliminary Studies. Polish Journal of Environmental Studies. 25 (5), 2221, 2016.

6. PUNZI M., ANBALAGAN A., BORNER R. A., SVENSSON B. M. JONSTRUP M., MATTIASSON B. Degradation of a textile azo dye using biological treatment followed by photo-Fenton oxidation: evaluation of toxicity and microbial community structure. Chemical Engineering Journal. 270, 290, 2015.

7. NOUREN S., SARWAR M., MUHI-UD-DIN G., YAMEEN M., BHATTI H.N., SOOMRO G.A., SULEMAN M., BİBİ I., KAUSAR A., NAZİR A., IQBAL M. Sweet Lime-Mediated Decolorization of Textile Industry Effluents. Polish Journal of Environmental Studies. 28 (1), 283, 2019.
8. HAO O.J., KIM H., CHIANG P.C. Decolorization of wastewater. Critical reviews in environmental science and technology. 30 (4), 449, 2000.

9. FERRAZ E. R., GRANDO M. D., OLIVEIRA D.P. The azo dye Disperse Orange 1 induces DNA damage and cytotoxic effects but does not cause ecotoxic effects in Daphnia similis and Vibrio fischeri. Journal of hazardous materials. 192 (2), 628, 2011.

10. PARVEZ S., VENKATARAMAN C., MUKHERJI S. A review on advantages of implementing luminescence inhibition test (Vibrio fischeri) for acute toxicity prediction of chemicals. Environment International. 32 (2), 265, 2006.

11. DÖKMECI A.H. Toxic Effects of Some Pharmaceuticals Drug Residues in Waters. Trakya University, Institute of Health Sciences, Toxicology Scientific, PhD Thesis, 2009 [In Turkish].

12. MA X.Y., WANG X.C., NGO H.H., GUO W., WU M.N., WANG N. Bioassay based luminescent bacteria: Interferences, improvements, and applications. Science of the Total Environment. 468, 1, 2014.

13. SONMEZ V.Z, SIVRI N, DOKMECI A.H. Determination of The Toxicity of Different Discharge Waters using Acute Toxicity Tests Approved for National Pollutant Discharge Permit in Turkey. Biosci Biotech Res Asia. 13(2), 2016.

14. URL 1: ABOATOX, http://www.aboatox.com/?page id $=297$ (accessed on 10 August 2018).

15. MICROTOX ${ }^{\circledR}$ MANUAL, Microbics Corporation. A Toxicity Testing Handbook. 1-5, Carlsbad, CA, USA, 1992.

16. REZAEI H., NAROOIE M.R., KHOSRAVI R., MOHAMMADI M.J., SHARAFI H., BIGLARI H. Humic acid removal by electrocoagulation process from natural aqueous environments. International Journal of Electrochemical Science. 13 (3), 2379, 2018.

17. ISO 11348-3:2007 Water quality - Determination of the inhibitory effect of water samples on the light emission of Vibrio fischeri (Luminescent bacteria test) - Part 3: Method using freeze-dried bacteria.

18. LAPPALAINEN J., JUVONEN R., NURMI J., KARP M. Automated color correction method for Vibrio fischeri toxicity test. Comparison of standard and kinetic assays. Chemosphere. 45 (4), 635, 2001.

19. KOVÁTS N., REFAEY M, VARANKA B., REICH K., FERINCZ A., ACS A. Comparison of conventional and Vibrio fischeri bioassays for the assessment of municipal wastewater toxicity. Environmental Engineering and Management Journal. 11 (11), 2073, 2012.

20. ISO 21338:2010 Water quality - Kinetic determination of the inhibitory effects of sediment, other solids and coloured samples on the light emission of Vibrio fischeri (kinetic luminescent bacteria test).

21. MAMINDY-PAJANY Y., GERET F., ROMÉO M., HUREL C., MARMIER N. Ex situ remediation of contaminated sediments using mineral additives: assessment of pollutant bioavailability with the Microtox solid phase test. Chemosphere. 86 (11), 1112, 2012.

22. SANTOS D.C., SILVA L., ALBUQUERQUE A., SIMÕES R., GOMES A.C. Biodegradability enhancement and detoxification of cork processing wastewater molecular size fractions by ozone. Bioresource technology. 147, 143, 2013.

23. SKOTTI E., ANASTASAKI E., KANELLOU G., POLISSIOU M., TARANTILIS P.A. Total phenolic content, antioxidant activity and toxicity of aqueous extracts from selected Greek medicinal and aromatic plants. Industrial Crops and Products. 53, 46, 2014. 
24. JARQUE S., MASNER P., KLÁNOVÁ J., PROKEŠ R., BLÁHA, L. Bioluminescent Vibrio fischeri assays in the assessment of seasonal and spatial patterns in toxicity of contaminated river sediments. Frontiers in microbiology. 7, 1738, 2016

25. URL 2: Republic of Turkey Ministry of Environment and Urbanization. Available online: http://cygm.csb.gov.tr/suve-toprak-yonetimi-i-541 (accessed on 17 May 2018).

26. SÖNMEZ V.Z., SIVRI N. Interlaboratory precision of acute toxicity tests using reference toxicant formaldehyde. Journal of Anatolian Environmental \& Animal Sciences. 1 (3), 96, 2016

27. FUNGARO D.A., GROSCHE L.C., PINHEIRO A., IZIDORO J.D.C., BORRELY S.I. Adsorption of methylene blue from aqueous solution on zeolitic material for color and toxicity removal. Orbital: The Electronic Journal of Chemistry. 2 (3), 235, 2011.

28. PIZARRO A.H., MOLINA C.B., RODRIGUEZ J.J. Decoloration of azo and triarylmethane dyes in the aqueous phase by catalytic hydrotreatment with Pd supported on pillared clays. RSC Advances. 6 (115), 113820, 2016.

29. OVEJERO G., RODRÍGUEZ A., VALLET A., WILLERICH S., GARCÍA J. Application of Ni supported over mixed $\mathrm{Mg}$-Al oxides to crystal violet wet air oxidation: The role of the reaction conditions and the catalyst. Applied Catalysis B: Environmental. 111, 586, 2012.

30. CHAMPAGNE P.P., RAMSAY J.A. Dye decolorization and detoxification by laccase immobilized on porous glass beads. Bioresource technology. 101 (7), 2230, 2010.
31. RYBCZYŃSKA-TKACZYK K., KORNIŁŁOWICZKOWALSKA T. Biotransformation and ecotoxicity evaluation of alkali lignin in optimized cultures of microscopic fungi. International Biodeterioration \& Biodegradation. 117, 131, 2017.

32. TSIRIDIS V., PETALA M., SAMARAS P., HADJISPYROU S., SAKELLAROPOULOS G., KUNGOLOS A. Interactive toxic effects of heavy metals and humic acids on Vibrio fischeri. Ecotoxicology and Environmental Safety. 63 (1), 158, 2006.

33. ASHWORTH J., NIJENHUIS E., GLOWACKA B., TRAN L., SCHENK-WATT L. Turbidity and color correction in the Microtox ${ }^{\circledR}$ bioassay. The Open Environmental Pollution and Toxicology Journal. 2, 1, 2010.

34. KURVET I., IVASK A., BONDARENKO O., SIHTMÄE M., KAHRU A. LuxCDABE - Transformed constitutively bioluminescent Escherichia coli for toxicity screening: Comparison with naturally luminous Vibrio fischeri. Sensors. 11 (8), 7865, 2011.

35. YU X., ZUO J., TANG X., LI R., LI Z., ZHANG, F. Toxicity evaluation of pharmaceutical wastewaters using the alga Scenedesmus obliquus and the bacterium Vibrio fischeri. Journal of Hazardous Materials. 266, 68, 2014.

36. TURKAY O., BARIŞÇI S., SILLANPÄÄ M. E-peroxone process for the treatment of laundry wastewater: A case study. Journal of Environmental Chemical Engineering. 5 (5), 4282, 2017.

37. KOVÁTS N., ÁCS A., KOVÁCS A., FERINCZ Á., TURÓCZI B., GELENCSÉR A. Direct contact test for estimating the ecotoxicity of aerosol samples. Environmental toxicology and pharmacology. 33 (2), 284, 2012. 